\title{
The Development of Social Knowledge Science Learning Devices Based on The Scientific Approach Through Interactive CDS In Class IV SD Muhammadiyah Aimas Sorong Regency
}

\author{
$1^{\text {st }}$ Mursalim $^{1}, 2^{\text {nd }}$ Sahiruddin $^{2}, 3^{\text {rd }}$ Jusmin $^{3}$ \\ \{mursalim47@gmail.com ${ }^{1}$, sahiruddinbuton@gmail.com ${ }^{2}$,jusminjosse328@gmail.com ${ }^{3}$ \}
}

Universitas Pendidikan Muhammadiyah Sorong, West Papua, Indonesia

\begin{abstract}
This study aims to examine the learning devices of IPS that teacher uses in teach the theme of My Hero's Pride, developing an IPS learning devise based on the scientific approach through interactive CDS, reviewing the effectiveness and practical of IPS learning devices based on the scientific approach through interactive CDS. The benefits of this study can be used as a reference in developing learning devices that comply with the 2013 curriculum approach. So, it is hoped that we can provide information to teachers how to develop student-centered learning tools, varied and innovative in implementing learning approaches while providing information about Implementation of Scientific approach assisted by interactive CD in SD Muhammadiyah Aimas Sorong Regency. This study is a type of Research and development with the use of the model 4D Thiagarajan. Data collection techniques are done by observation, study result test, poll, and documentation. The Validation analysis and learning devices are conducted with expert assessments. Data on student learning outcomes are analyzed in a quantitative descriptive. The practical analysis of learning devices is done in a qualitative descriptive. Learning devices with an interactive $\mathrm{CD}$-assisted scientific approach, as they meet effective indicators, among others, students ' skills become active, learning outcomes have been achieved, student learning outcomes of experimental groups better than the control group and students respond positively to the implementation of learning.
\end{abstract}

Keywords: Scientific learning, interactive CDS

\section{Introduction}

The 2013 curriculum is designed to strengthen student competence from the knowledge, skills, and overall attitude. The integrity includes the basic competencies in the attitudes, knowledge, and skills of each subject. The submission of the subject matter is also integrated with a scientific approach. Among the subjects that follow the provisions are IPS courses.

IPS are subjects that equip students to recognize concepts relating to the lives of people and their environment, providing the ability to think logically and critically, possess skills in social life, have a commitment and awareness of social and humanitarian values and has the ability to engage, cooperate and compete in a community that is compound at a local, national or global level. In order to produce good and competent graduates, the delivery of materials must be taught with learning devices that correspond to the level of understanding and development of students, so that students can understand each material received. In the end, 
learning activities with the use of appropriate training devices can increase the acquisition of students ' learning outcomes to the fullest.

The fact in the field that the implementation of learning in order to implement the curriculum today still face some problems. The problem that is coloring IPS learning today is the IPS course as subjects that are less interesting, even considered insignificant and felt less beneficial to the academic development. The understanding of the content, meaning, and purpose of the IPS learning has not been understood deeply. The principle of learning has not been beneficial to student psychiatric development. Even among the teachers, IPS lessons are inserted into a group of subjects that are not prioritized in teaching and learning activities. In fact, the concept of learning IPS subject is expected to be very beneficial for students in shaping personality in order to achieve the social competence of students. As the Fauziyah study (2011) shows that teachers should be encouraged to perform more learning to develop creative thinking skills.

Based on the results of the interview with the teacher of Grade IV Elementary School Muhammadiyah Aimas Sorong District identified several problems that the teacher has not been able to develop learning devices that lead to the Scientific approach, whereas teachers are required to mastering the implementation of the 2013 curriculum learning device so that it will impact student learning outcomes. In addition, the learning model used by teachers is less innovative, unwillingness/limitation of teaching materials, lack of facilities and infrastructure. Based on the factors causing the learning difficulties of the students above, researchers are more emphasis on the teacher's factor that is the approach used in learning IPS that are less precise and still use a less innovative learning approach So the learning process tends to use conventional approaches. In other words, the curriculum used is Kurikululum 2013 but the implementation is still using KTSP curriculum. In fact, teachers are required to master the scientific approach.

Another problem that arises is the implementation of learning is still in direct form. The verbal transfer of knowledge is still very dominant. In other words, learning is still centered on teachers (teacher center). So that learning activities are just as limited as listening to lectures and making notes, where it is very tedious for students to eventually make students very difficult to follow and capture the essence of learning material.

Based on the explanation above, teachers ' difficulties in developing learning devices are integrated to develop the students ' learning results, the focus of attention is interesting enough to be examined. Responding to this phenomenon, so that the learning process can trigger increased learning outcomes oriented towards the 5 stages of are (observing), Questioning (minister), Associating (Reasoning), Experimenting (try), Networking ( Forming a network).

Learning devices are one of the forms of preparation made by the teacher before they do the learning process. Learning devices for IPS include the Learning Implementation Plan (RPP) to be an important document in the 2013 curriculum which is a guideline in implementing the learning activities.

Moreover, if combined with technological tools, it will give the teacher easy to teach and students will be easier to capture the material that has been taught. One of them is learning with assisted interactive CDS is expected to motivate students in following the IPS ' study.

Some of the previous study shows that both quantitative studies and development studies that all gave the results concluded that learning with the Scientific approach is effective to improve student learning outcomes for students, process skills, interests and motivational learning and learning outcomes. 
As for the differences of previous studies with this development study, namely will be developed learning device with an interactive process of processing material adapted to the Scientific approach.

Based on the background above, researchers are interested to develop a learning device based on the Scientific approaches with interactive CD Media in grade IV students Elementary School Muhammadiyah Aimas Sorong Regency. The problem in this study include: (1) How the characteristics of learning device in class IV IPS Elementary School Muhammadiyah Aimas District Sorong. (2) How the validity and effectiveness of learning device based IPS scientific approach with interactive CD media in grade IV students Elementary School Muhammadiyah Aimas Sorong Regency.

\section{Literature Review}

Learning devices are the equipment that teachers need when providing learning. Without such equipment the teacher could not teach well. Because learning devices are a prerequisite before learning in class. Ibrahim in Trianto (2013:96) reveals the learning devices needed to manage the teaching process can be a syllabus, learning Implementation Plan (RPP), teaching materials, student activity sheets (LKS), learning Media, and Evaluation instrument or study result test. The results of the Hayumuti study (2016) states that the use of interactive multimedia CDS is used to help teachers teach and improve student learning outcomes and to improve student learning activities. In other words, learning with CDS is very effective to improve In other words, learning with CDS is very effective to improve teacher skills in teaching process.

The conceptual defendant of the study Implementation Plan (RPP) is widely disclosed by some experts. One of them in Permendikbud No. 652013 that the Learning Plan (RPP) is the plan of face-to-face learning for one or more meetings, RPP is developed from syllabus to direct learners' learning activities. In the effort to achieve basic competency. Majid (2014:226) also reveals that the learning Implementation plan (RPP) is a plan describing the procedure and organizing the learning to achieve a basic competency set in the content standard and outlined in Syllabus.

The LKS are sheets containing a barrage of activities that students must do in solving learning problems. But in this case there are various opinions that mention the concept of LKS such as Prastowo (2014:204) explaining the LKS or student worksheets is a teaching material that has been packaged in such a way, so that learners are expected to Independently study the material.

According to Ketut (2013), Compact Disk (CD) is one of the most multimedia forms that can help sharpen the message that is conveyed with the benefits of attracting senses and attracting interest, as it combines the view, sound, and movement. The interactive CD that will be used in this study is an interactive CD that contains about the theme of my hero's pride.

\section{Method of the Study}

This type of study includes the method of Research and Development 4D Thiagarajan in (Sugiyono, 2013:45). The procedures modification of the study is divided into defining stage (define), design, and develop. The trial stages are carried out in quasi experiments with pre- 
test and post test control group design. Studi pengembangan ini dilaksanakan di SD Muhammadiyah Aimas Kabupaten Sorong. The subject of the test class was conducted on the class IV students of SD Muhammadiyah Aimas Sorong Regency with class group used as many as 2 classes, 1 class of experiments for learning using the scientific approach through $\mathrm{CD}$ Interactive and 1 class control for conventional learning. The data collection techniques used in this study include data on the validity of learning devices taken using validation sheets, data on student learning activities taken by observation using observation sheets, SDTA Student learning results are taken with multiple choice tests, and student response data is taken using a poll. The analysis of the study includes validity and learning devices with categories not well up to good categories. The effectiveness of learning devices uses the following formulas:

$$
\frac{\frac{x}{n}-\pi_{0}}{\sqrt{\frac{\pi_{0}\left(1-\pi_{0}\right)}{n}}}
$$

The formula above compares with the $Z$ value of the table with a real-level $\alpha=5 \%$. The decision of making criteria, reject Ho if zarithmetic $\geq \mathrm{z} 0,5-\square$, and Ho accepted if zarithmetic $<$ z 0, 5- $\square$. Independent Sample T-test analysis is used to determine students' learning results by using interactive CDS better than conventional learning. The formula used to test independent sample T-test is as follows:

Statistical test formula used:

$$
t=\frac{\bar{x}_{1}-\bar{x}_{2}}{s \sqrt{\frac{1}{n_{1}}+\frac{1}{n_{2}}}}
$$

\section{Result}

A characteristic of learning device development that is based on the scientific approach through interactive CDS in class IV IPS in SD Muhammadiyah Aimas. The learning device components developed are RPP, LKS, Media (interactive CDS). The Characterisitic devices developed include learning devices that contain aspects of the Scientific approach, interactive CD-assisted learning devices.

A valid learning device is a learning device developed based on device development procedures and has been validated by a validators with a minimal assessment and provides recommendations for use. In this study, the validator used amounted 3 peoples from the lecturers of Elementary School Teacher Education Study Program.

A validator assessment of developed learning devices (RPP, student Learning test, Interacryphal Media) generally declares a well-categorized and usable learning device development with little revision. In addition to providing assessments, the validators provide input and advice on learning devices developed to be worthy and good to use. The average value of learning device validation results from the three validators can be seen in the following table. 
Table 1. Learning Device Validation Results

\begin{tabular}{|c|c|c|c|c|c|c|}
\hline \multirow[t]{2}{*}{ No } & \multirow[t]{2}{*}{ Devices } & \multicolumn{3}{|c|}{ Validator } & \multirow[t]{2}{*}{ Average } & \multirow[t]{2}{*}{ Criteria } \\
\hline & & I & II & III & & \\
\hline 1 & RPP & 4,73 & 4,87 & 4,73 & 4,78 & Excellent \\
\hline 2 & LKS & 4.54 & 4,72 & 4,81 & 4,77 & Excellent \\
\hline 3 & Media & 4,67 & 4,83 & 4,92 & 4,81 & Excellent \\
\hline \multirow[t]{2}{*}{4} & THB & 4,30 & 4,70 & 4,77 & 4,59 & Excellent \\
\hline & & \multicolumn{3}{|c|}{ Average } & 4,73 & Excellent \\
\hline
\end{tabular}

The student's learning results are seen from the achievement of student learning outcomes and the differences between classes taught using the scientific approach through interactive CDS with conventional classes. The average experimental student learning result is 82.59 while in the control class is 63.34.

Individual submission is calculated by calculating the value of each student with a specified KKM of 70. In classical submission, it is calculated by the proportion test of T-Test.

Based on the student's submission from the total number of 38 students, 34 students are thoroughly studied and the remaining 7 students are not thoroughly studied. The classical learning test is calculated using the program SPSS 16. The following is a data output test of the learning submission in the classical table 2.

Table 2. The Output of Classical Submission Test

\begin{tabular}{|c|c|c|c|c|c|}
\hline & \multicolumn{5}{|c|}{ Test Value $=82.59$} \\
\hline & \multirow[b]{2}{*}{$\mathrm{T}$} & \multirow[b]{2}{*}{ Df Sig. (2-tailed) } & \multirow[b]{2}{*}{ Mean Difference } & \multicolumn{2}{|c|}{$95 \%$ Confidence Interval of the Difference } \\
\hline & & & & Lower & Upper \\
\hline pres_bel & -.002 & 38.998 & -.005 & -4.08 & 4.07 \\
\hline
\end{tabular}

Paired-Sample Statistics

\begin{tabular}{lllll}
\hline & & \multicolumn{2}{l}{$\begin{array}{l}\text { Std. } \\
\text { N }\end{array}$} & $\begin{array}{l}\text { Std. Eean } \\
\text { Deviation }\end{array}$ \\
Mean
\end{tabular}

Classical-Test hypothesis: $\mathrm{H}_{0}: \pi<75 \%$ (student learning is less than $75 \%$ ) $\mathrm{H}_{1}: \pi \geq 75 \%$ (student learning is more than or equal to $75 \%)$

Based on the output above, it looks the value of $\operatorname{sig}=0.998=99.8 \%>5 \%$, then the Ho is rejected. It was concluded that the proportion of students learning is more than or equal to $75 \%$. The number of students reaching the KKM value is 34 students. The percentage of students' who have value of the $\mathrm{KKM}=\frac{34}{38} x 100=82,59 \%$. Visible on the output paired sample t test value or rate of 82.59 .

The results of the two sample comparative tests can be seen in the following table 
Table 3. Results of Two Sample Comparison Tests

\begin{tabular}{|c|c|c|c|c|c|c|}
\hline \multicolumn{7}{|c|}{ t-test for Equality of Means } \\
\hline \multirow[b]{2}{*}{$\mathrm{T}$} & \multirow[b]{2}{*}{ Df } & \multirow{2}{*}{$\begin{array}{l}\text { Sig. } \\
(2- \\
\text { tailed })\end{array}$} & \multirow{2}{*}{$\begin{array}{l}\text { Mean } \\
\text { Difference }\end{array}$} & \multirow{2}{*}{$\begin{array}{l}\text { Std. } \\
\text { Error } \\
\text { Differ } \\
\text { ence }\end{array}$} & $\begin{array}{l}95 \% \\
\text { Interval } \\
\text { Difference }\end{array}$ & $\begin{array}{l}\text { Confidence } \\
\text { of the }\end{array}$ \\
\hline & & & & & Lower & Upper \\
\hline 5.894 & 72 & .000 & 19.242 & 3.265 & 12.732 & 25.751 \\
\hline 5.787 & 61.444 & .000 & 19.242 & 3.325 & 12.594 & 25.889 \\
\hline
\end{tabular}

Based on table 3 , the value of $\operatorname{sig}=0.000=0 \%<5 \%$ then Ho is rejected or received $\mathrm{H} 1$. Test criterion: Ho is accepted if arithmetic $<$ ttable.

At $\alpha=5 \%$ with $\mathrm{dk}=38+36-2=72$, obtained $t_{\text {table }}=1,666$ because $t_{\text {arithmetic }}>$ $t_{\text {table }}$, then $H_{0}$ is rejected and it means $H_{1}$ is accepted, it is concluded that the learning IPS using interactive CDS based on scientific approaches are able to give change Improved Student learning Outcomes. By rejecting $H_{0}$ and accepted $H_{1}$ so, it is a further test and generating output in table 4.

Tabel 4. Perbedaan Rata-rata Hasil Belajar Siswa

\begin{tabular}{llllll}
\hline & Class & $\mathrm{N}$ & Mean & Std. Deviation & Std. Error Mean \\
\hline \multirow{2}{*}{ pres_bel } & Eexperimental & 38 & 82.59 & 12.911 & 2.016 \\
\cline { 2 - 5 } & Control & 32 & 63.34 & 14.955 & 2.644 \\
\hline
\end{tabular}

The increase of students' learning outcomes is 19.25 , and can be seen in the following diagram 1.

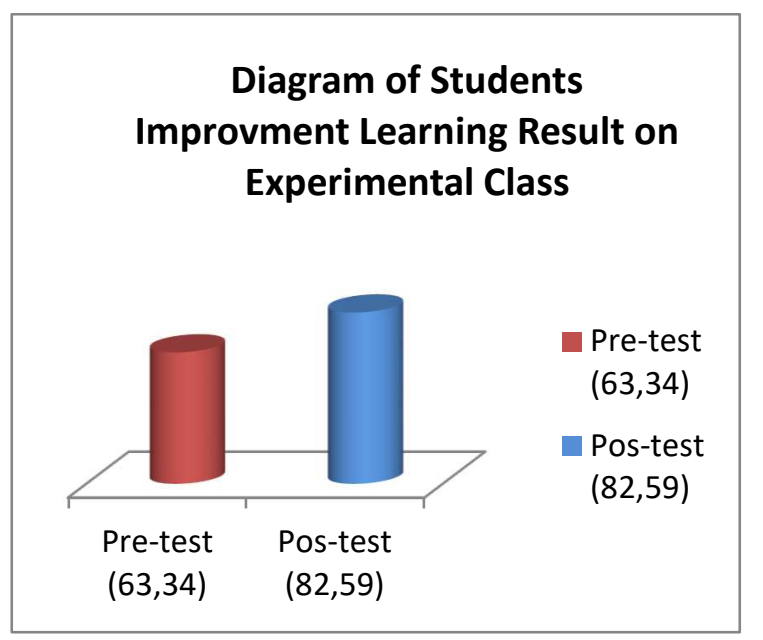

Fig 1. Students Improvment Learning Result on Experimental Class

The practicality of learning devices in this study is seen from the student response questionnaire. The student response is measured using the student response poll to the IPS 
learning process in an interactive CD. The results of the poll are distributed to students that students' responses to the learning process by using interactive CDS. The results gained from the student response poll for learning is an average of $84.3 \%$ of students have a positive response to learning after the IPS using an interactive CD. The rest is a negative response of $15.7 \%$. Based on the results of the questionnaire responses of students it can be concluded that the media and learning tools are practical.

\section{Conclusions}

Based on the results of the study conducted about the development of learning devices in IPS course based on the scientific approach through interactive CDS can be concluded into several things:

1) Characteristics of results of learning devices in IPS subject based on the scientific approach through the theme of my hero's' pride interactive CD was developed in this case that is RPP, LKS, interactive CDS that contain the elements of the Scientific approach that contain phases or The 5-M stage are observing, testing, reasoning, trying, and communicating.

2) An IPS learning device based on the scientific approach through an interactive CD on my hero theme pride is valid after through revision. The validation results of learning devices by the validators indicate that the developed device has a good classification with a slight revision.

3) Learning devices with an interactive CD-assisted trough scientific approach, as they meet effective indicators, among others, students' skills become active, learning outcomes have been achieved, student learning outcomes of experimental groups are better than the control groups and students respond positively to the implementation of learning.

\section{References}

[1] Abidin, Y. 2014. Desain Sistem Pembelajaran dalam Konteks Kurikulum 2013. Bandung : Refika Aditama.

[2] Aprilia, Linda. 2014. Penerapan Perangkat Pembelajaran Materi Kalor melalui Pendekatan Saintifik dengan Model Pembelajaran Guided Discovery Kelas X SMA. Jurnal Inovasi Pendidikan Fisika (JIPF), Vol. 03 No. 03.

[3] Fauziyah, N. 2011. Analisis kemampuan guru dalam mengembangkan ketrampilan berfikir kreatif siswa dasar kelas $V$ pada pembelajaran ilmu pengetahuan alam. UPI. jurnal pedagogik pendidikan Dasar, Volume 3 No. 1.

[4] Hayumuti. 2016. Penggunaan Multimedia CD Interaktif Dalam Peningkatan Aktivitas dan Hasil Belajar IPA Tema Selalu Berhemat Energi Di Kelas IV SDN Klanderan Kediri. Jurnal Pendidikan, 2016, Volume: 1 Nomor: 7 Bulan Juli.

[5] Hosnan, M. 2014. Pendekatan Saintifik dan Kontekstual dalam Pembelajaran Abad 21. Bogor: Ghalia Indonesia.

[6] Ketut, Erni Suardani. 2013. Pengaruh Media CD Interaktif Berbantuan LKS Terhadap Motivasi dan Hasil Belajar IPA Kelas V Di SD 1,2,5 Banyuasri-Singaraja. e-Journal Program Pascasarjana Universitas Pendidikan Ganesha Jurusan Pendidikan Dasar, Vol. 3.

[7] Majid, A. 2012. Perencanaan Pembelajaran Mengembangkan Standar Kompetensi Guru. Bandung: Rosda Karya.

[8] Majid, A. 2014. Impelemetnasi Kurikulum 2013: Kajian Teoritis dan Praktis.

[9] Yogyakarta: Insan Madani.

[10] Nurmariza Arni. 2016. Pengembangan Bahan Ajar Berbasis Aktivitas dengan Media CD 
Interaktif Pada Materi Indera Pendengaran dan Sistem Sonar. Jurnal Pendidikan Sains Pascasarjana Universitas Negeri Surabaya, 2016. Vol. 6, No. 1, Nov.

[11] Prastowo, A. 2014. Panduan Kreatif Membuat Bahan Ajar Inovatif. Jogyakarta: Diva Press.

[12] Rinjani, Ni Made Ayu Gunung. 2013. Pengembangan CD Interaktif Pembelajaran Statistik dengan Mengaplikasikan Spss (Statistical Package For Social Science) Sebagai Pengolah Data. e-Journal Program Pascasarjana Universitas Pendidikan Ganesha, 2013, Volume 3.

[13] Sanjaya. 2008. Perencanaan dan Desain Sistem Pembelajaran. Bandung: Kencana Prenada Media Group.

[14] Sugiyono. 2013. Metode Studi Pendidikan: Pendekatan Kuantitatif, kualitatif, dan R\&D. Bandung: Alfabeta.

[15] Trianto. 2013. Model Pembelajaran Terpadu. Jakarta: Bumi Aksara.

[16] Yusa, I Made Marthana. 2013. Pengembangan Model Pembelajaran Huruf Hiragana Dalam Wujud CD Interaktif Untuk Siswa Kelas IV SD. Jurnal Nasional Pendidikan Teknik Informatika (JANAPATI), Volume 2, Nomor 